\title{
Effect of Different Rates of Nitrogen and Phosphorous on Growth and Nodulation of Glycine max in the Eastern Region of Sri Lanka
}

\author{
Somasundaram Sutharsan*, Varuni Yatawatte, Shanmugalingam Srikrisnah \\ Department of Crop Science, Faculty of Agriculture, Eastern University, Vantharumoolai, Sri Lanka \\ Email: ${ }^{*}$ sutharsans@esn.ac.lk
}

Received 2 July 2016; accepted 27 August 2016; published 30 August 2016

\begin{abstract}
An experiment was conducted to study the effects of different rates of nitrogen and phosphorous on the nodulation and growth of soybean. The pot experiment was conducted under a rain shelter in Agro Technology Park, Eastern University, Sri Lanka. The experimental design was CRD with four replicates. Different fertilizer combinations were used as treatments such as T1-30N:150P: 75K: kg/ha, T2-70N:150P:75K: kg/ha, T3 (control)-50N:150P:75K: kg/ha, T4-50N:125P:75K: kg/ ha and T5-50N:175P:75K: $\mathrm{kg} / \mathrm{ha}$. The results revealed that there were significant $(p<0.05)$ differences among the treatments on plant height, leaf area, plant dry biomass and nodulation. It was observed that T4 showed significant increment in growth and nodulation of soybean. The application of fertilizer combination with reduced amount of phosphorous fertilizer could be used to get maximum growth and nodulation of soybean in Batticaloa district of Sri Lanka.
\end{abstract}

\section{Keywords}

Combinations, Fertilizer, Phosphorous, Soybean

\section{Introduction}

Soybean (Glycine max L.) is known as an important crop worldwide. It is used as a good source of vegetarian protein as well as vegetable oil. It has unmatched composition of 40 percent protein and 20 percent oil and nutritional superiority on account of containing essential amino acids, unsaturated fatty acids, carbohydrates, vitamins and minerals [1] . Plant growth and seed yield of soybean increased when nitrogen was initially added [2]. The growth parameters such as LAI, plant biomass, and leaf photosynthesis reduced due to limited nitrogen availability [3]. Nitrogen $(\mathrm{N})$ fertilizer can increase the production of total dry matter, which can improve the potential of plant to produce more pods, seeds and ultimately grain yield [3]. It has been proven that $\mathrm{P}$ increases weight and number of root nodules and also can enhance the pod yield [4]. Cultivation of soybean is very low in Batticaloa district due to its poor germination as well as poor yield. It may be increased using more amounts of

${ }^{*}$ Corresponding author.

How to cite this paper: Sutharsan, S., Yatawatte, V. and Srikrisnah, S. (2016) Effect of Different Rates of Nitrogen and Phosphorous on Growth and Nodulation of Glycine max in the Eastern Region of Sri Lanka. World Journal of Engineering and Technology, 4, 14-17. http://dx.doi.org/10.4236/wjet.2016.43B003 
fertilizers. Applying sufficient rate of $\mathrm{N}$ in this stage is very important since applying too much $\mathrm{N}$ leads to environmental pollution. The biosphere is in endangered situation because of excess application of synthetically compounded inorganic fertilizers like Urea and Triple Super Phosphate (TSP). However, there is no any proof that clearly states about the rate of nitrogen and phosphorous, which is the most suitable specifically for sandy regosols in Batticaloa district. Therefore the experiment was conducted to study the effects of different rates of nitrogen and phosphorous on the nodulation and growth of soybean.

\section{Materials and Methods}

The pot experiment was conducted under the rain shelter in Agro Technology park, Eastern University, Sri Lanka from November to December $2015\left(70^{\circ} 43^{\prime} \mathrm{N}\right.$ and $\left.810^{\circ} 42^{\prime} \mathrm{E}\right)$. The main soil type of this region is sandy regosol. The experimental design was CRD with five treatments and four replicates. $20 \mathrm{~cm}$ in diameter and $24 \mathrm{~cm}$ in height plastic pots, filled with soil mixture of top soil, red soil and compost at the rate of 1:1:1 were used. Different fertilizer combinations were used as treatments such as T1-30N:150P:75K: kg/ha, T2-70N:150P:75K: kg/ha, T3 (control)-50N:150P:75K: kg/ha, T4-50N:125P:75K: kg/ha and T5-50N:175P:75K: kg/ha. All agronomic practices were done as department of agriculture recommendations. The measurements were taken at 6 weeks after sowing (WAS). The data were analyzed using Analysis of variance (ANOVA) performed by SAS and mean comparison was performed within treatments using DMRT at 5\% significant level.

\section{Results and Discussion}

Plant height was decreased when the amount of $\mathrm{N}$ is decreased in fertilizer combination. These results were (Table 1) confirmed with Starling et al. (2000). There was significant effect $(p<0.05)$ of different levels of $\mathrm{P}$ in fertilizer combination at $6^{\text {th }}$ WAS. When the soil $\mathrm{N}$ supply is not enough, plant $\mathrm{N}$ demand could be met with $\mathrm{N}$-fertilizer. Therefore the changing of rate of $\mathrm{N}$ and $\mathrm{P}$ fertilizer combination was affected the plant height. Although there were no significant different $(p<0.05)$ between T2, T4 and T5 at $6^{\text {th }}$ WAS, the best treatment was T4. Because the most economical fertilizer combination was T4 due to the high price of Triple Super Phosphate compared to Urea.

Figure 1 showed that reduction of nitrogen content in the fertilizer combination than control did not affect average leaf area. Increased rate of $P$ in the fertilizer combination did not show any effect on leaf area at $6^{\text {th }}$ WAS. But the fertilizer combination with reduced amount of P (T4) was given the maximum leaf area. There were significant different $(p<0.05)$ between T2 and control. This could be due to higher $\mathrm{N}$ content in the fertilizer combination. It was found by [5]. Based on the above results it could be able to conclude that there is no statistical difference between T4 and T2 whereas T4 is best, because it was contained with reduced level of TSP which has high price and cause many hazardous effects to environment. The results which were obtained in plant dry biomass (in Table 2) showed that there was an effect of different levels of phosphorus in the fertilizer combination on average dry root weight. The increment of dry root weight in T4 was due to higher root development of soybean plants to find more nutrients from below levels of the soil when $\mathrm{P}$ was insufficient in the immediate root zone [6].

Table 1. Effect of different rates of nitrogen and phosphorous on plant height of Glycine max.

\begin{tabular}{cccccc}
\hline \multirow{2}{*}{ Treatment } & \multicolumn{5}{c}{ Plant height (cm) } \\
\cline { 2 - 6 } & $2^{\text {nd }}$ WAS & $3^{\text {rd }}$ WAS & $4^{\text {th }}$ WAS & $5^{\text {th }}$ WAS & $6^{\text {th }}$ WAS \\
\hline T1 & $21.38 \pm 1.42 \mathrm{a}$ & $21.67 \pm 1.14 \mathrm{a}$ & $40.63 \pm 2.19 \mathrm{a}$ & $45.18 \pm 1.34 \mathrm{c}$ & $65.00 \pm 0.85 \mathrm{~b}$ \\
T2 & $21.00 \pm 0.74 \mathrm{a}$ & $22.05 \pm 0.69 \mathrm{a}$ & $39.48 \pm 1.40 \mathrm{a}$ & $49.42 \pm 0.69 \mathrm{ab}$ & $69.25 \pm 1.11 \mathrm{a}$ \\
T3 & $21.13 \pm 1.01 \mathrm{a}$ & $21.63 \pm 0.85 \mathrm{a}$ & $41.00 \pm 1.27 \mathrm{a}$ & $45.95 \pm 1.09 \mathrm{bc}$ & $65.75 \pm 0.64 \mathrm{~b}$ \\
T4 & $19.88 \pm 0.83 \mathrm{a}$ & $20.60 \pm 1.02 \mathrm{a}$ & $39.50 \pm 1.63 \mathrm{a}$ & $49.73 \pm 1.28 \mathrm{a}$ & $70.05 \pm 1.04 \mathrm{a}$ \\
T5 & $20.13 \pm 1.55 \mathrm{a}$ & $19.67 \pm 1.75 \mathrm{a}$ & $38.70 \pm 1.83 \mathrm{a}$ & $49.55 \pm 1.22 \mathrm{ab}$ & $69.78 \pm 1.71 \mathrm{a}$ \\
F test & $\mathrm{ns}$ & $\mathrm{ns}$ & $\mathrm{ns}$ & $*$ & $*$ \\
\hline
\end{tabular}

\footnotetext{
${ }^{*}=$ Significant at $5 \%$ level of probability, ns = Not significant. Mean values in a column having the dissimilar latter/letters indicate significant differences at $5 \%$ level of significant (DMRT).
} 
The reduction of nitrogen amount in the fertilizer combination did not have effect on dry root weight. But the increment of nitrogen amount in the fertilizer combination affected on it. Increasing of root density in the immediate area caused to increase of total dry root weight. The best results were given by T4 for plant dry biomass.

Number of total nodules showed significant effect with different fertilizer combinations (in Table 3). The total number of nodules was increased by $81 \%$ in T4 while it was reduced $37 \%$ in $\mathrm{T} 2$ than control. These results were clearly showed that there was a considerable effect of nitrogen $(\mathrm{N})$ and phosphorous $(\mathrm{P})$ amount on total nodules in soybean. Nodule formation is highly influenced by nitrogen. It has been reported that low levels of nitrate and ammonium stimulate nodulation, whereas high concentrations of these nutrients inhibit nodule formation, number of infection sites in the root, nodule development, $\mathrm{N}$ fixation in pre-existing nodules, and nitrogenase activity [7]. Nodule formation was highly influenced by phosphorous also. Reduction of $\mathrm{P}$ in fertilizer combination was caused to increase number of effective and total nodules as well as nodule weight [8].

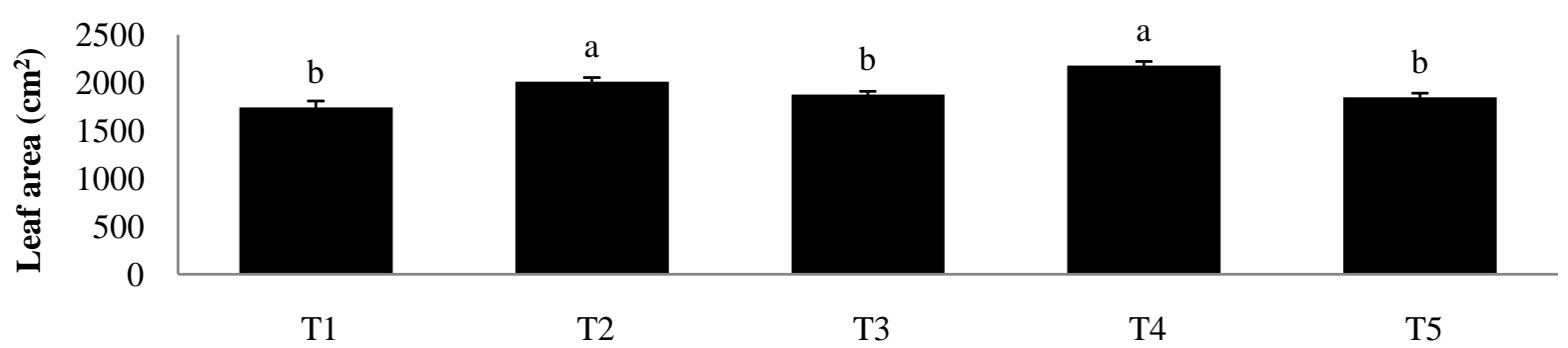

Figure 1. Effect of different rates of $\mathrm{N}$ and $\mathrm{P}$ on leaf area of Glycine max.at 6th WAS figure).

Table 2. Effect of different rates of N and P on dry root and shoot weight of Glycine max.

\begin{tabular}{ccc}
\hline Treatment & Dry root weight (g) & Dry shoot weight (g) \\
\hline T1 & $2.928 \pm 0.128 \mathrm{dc}$ & $10.550 \pm 0.372 \mathrm{c}$ \\
T2 & $3.125 \pm 0.069 \mathrm{bc}$ & $12.735 \pm 0.181 \mathrm{~b}$ \\
T3 & $2.803 \pm 0.147 \mathrm{~d}$ & $12.383 \pm 0.453 \mathrm{~b}$ \\
T4 & $3.590 \pm 0.028 \mathrm{a}$ & $13.833 \pm 0.139 \mathrm{a}$ \\
T5 & $3.343 \pm 0.067 \mathrm{ab}$ & $12.778 \pm 0.273 \mathrm{~b}$ \\
F test & $*$ & $*$
\end{tabular}

${ }^{*}=$ Significant at $5 \%$ level of probability, ns = Not significant. Mean values in a column having the dissimilar latter/letters indicate significant differences at $5 \%$ level of significant (DMRT).

Table 3. Effect of different rates of $\mathrm{N}$ and $\mathrm{P}$ on nodules number and nodule weight of Glycine max at 6th WAS.

\begin{tabular}{cccc}
\hline Treatment & Total nodules & Effective nodules & Nodule weight (g) \\
\hline T1 & $108.00 \pm 2.48 \mathrm{~b}$ & $37.25 \pm 0.85 \mathrm{~b}$ & $3.6654 \pm 0.256 \mathrm{~b}$ \\
T2 & $52.25 \pm 4.13 \mathrm{~d}$ & $14.50 \pm 0.87 \mathrm{~d}$ & $2.9555 \pm 0.267 \mathrm{c}$ \\
T3 & $83.50 \pm 4.35 \mathrm{c}$ & $30.50 \pm 2.63 \mathrm{bc}$ & $3.8032 \pm 0.193 \mathrm{bc}$ \\
T4 & $150.75 \pm 5.33 \mathrm{a}$ & $49.00 \pm 3.72 \mathrm{a}$ & $4.7603 \pm 0.306 \mathrm{a}$ \\
T5 & $105.00 \pm 3.32 \mathrm{~b}$ & $29.50 \pm 2.33 \mathrm{c}$ & $3.7350 \pm 0.099 \mathrm{~b}$ \\
F test & $*$ & $*$ & $*$ \\
\hline
\end{tabular}

\footnotetext{
${ }^{*}=$ Significant at $5 \%$ level of probability, ns = Not significant. Mean values in a column having the dissimilar latter/letters indicate significant differences at $5 \%$ level of significant (DMRT)
} 


\section{Conclusion}

Application of different rates of nitrogen and phosphorous had significant effects on tested parameters of soybean. The T4 fertilizer combination which was consisted with 50N:125P:75K kg/ha caused to increase plant height, leaf area, plant dry biomass as well as root nodulation. From these results it could be concluded that T4 fertilizer combination which consisted 50N:125P:75K kg/ha increased plant growth and nodulation in soybean.

\section{References}

[1] Pawar, R.S., Wagh, V.M., Panaskar, D.B., Adaskar, V.A. and Pawar, P.R. (2011) A Case Study of Soybean Crop Production, Installed Capacity and Utilized Capacity of Oil Plants in Nanded District, Maharashtra, India. Advances in Applied Science Research, 2, 342-350.

[2] Starling, M.E., Wood, C.W. and Weaver, D.B. (2000) Late-Planted Soybeans Respond to Nitrogen Starter. Fluid Journal, 28, 26-30.

[3] Caliskan, S., Ozkaya, I., Caliskan, M.E. and Arslan, M. (2008) The Effects of Nitrogen and Iron Fertilization on Growth, Yield and Fertilizer Use Efficiency of Soybean in a Mediterranean-Type Soil. Field Crops Research, 108, 126-132. http://dx.doi.org/10.1016/j.fcr.2008.04.005

[4] Jones, G.D., Lutz, J.A. and Smith, T.J. (1977) Effects of Phosphorus and Potassium on Soybean Nodules and Seed Yield. Agronomy Journal, 69, 1003-1006. http://dx.doi.org/10.2134/agronj1977.00021962006900060024x

[5] Carpici, E.B. (2011) Changes in Leaf Area Index, Light Interception, Quality and Dry Matter Yield of an Abandoned Rangeland as Affected by the Different Levels of Nitrogen. Turkish Journal of Field Crops, 16, 117-120.

[6] Harris, R.W. (1992) Arboriculture: Integrated Management of Landscape Trees, Shrubs, and Vines. Prentice-Hall International, 2 p.

[7] Zahran, H.H. (1999) Rhizobium-Legume Symbiosis and Nitrogen Fixation under Severe Conditions and in an Arid Climate. Microbiology and Molecular Biology Reviews, 63, 968-989.

[8] Sinclair, T.R. and Vadez, V. (2002) Physiological Traits for Crop Yield Improvement in Low N and P Environments. Plant and Soil, 245, 1-15. http://dx.doi.org/10.1023/A:1020624015351

\section{Submit or recommend next manuscript to SCIRP and we will provide best service for you:}

Accepting pre-submission inquiries through Email, Facebook, LinkedIn, Twitter, etc.

A wide selection of journals (inclusive of 9 subjects, more than 200 journals)

Providing 24-hour high-quality service

User-friendly online submission system

Fair and swift peer-review system

Efficient typesetting and proofreading procedure

Display of the result of downloads and visits, as well as the number of cited articles

Maximum dissemination of your research work

Submit your manuscript at: http://papersubmission.scirp.org/ 